\title{
Measuring Green Value in Housing Market: Evidence from Hangzhou
}

\author{
Haizhen Wen", Yuqin Han ${ }^{\text {b }}$ Zaiyuan Guic \\ The Center for Real Estate Study, Zhejiang University, Hangzhou 310058, China \\ *wenhaizhen@zju.edu.cn, bhyq2662@163.com, couizy@zju.edu.cn
}

Keywords: Housing price; Green marketing; Hedonic price model; Price premium

\begin{abstract}
With the rapid development of economy, homebuyers prefer to buy the residential complexes with green characteristics, such as living comfort and energy efficiency. As a new trend of housing development model, green housing which is consistent with the concept of sustainability has been promoted positively. More and more real estate developers have used marketing strategy and green words to advertise their residential products. Based on the Hangzhou newly-built housing transaction data in 2016, this study constructs the hedonic price model to quantitatively analyze whether such green marketing have an effect on housing prices. The empirical results show that green marketing really yields a price premium and allows developers to charge such premium that homebuyers have willingness to pay. This study can provide a theoretical basis for government to make relevant policies, as well as real estate developer to determine development decisions.
\end{abstract}

\section{Introduction}

It is generally accepted that buildings play an important role in urbanization, whereas the construction and operation of buildings consume a lot of resources and result in negative effects on the environment. As environmental awareness becomes more and more prevalent, green certification system has emerged around the world. In 2008, the Ministry of Housing and Urban-Rural Development (MOHURD) promoted a nationwide program the Chinese Green Building Label (CGBL) and established the certification rating system which is appropriate for Chinese buildings [1]. Many scholars have studied the price premium effect caused by a green certification or label [1-7]. They found a positive relationship between such green certification or label and housing prices, which indicates that certification or label carries a price premium for housing. Recently, real estate developers have marked their products as ecological or technological, combined with concrete green description, to increase homebuyers' incentives to pay for such housing. Using the 2016 new housing transaction data obtained from Hangzhou Real Estate Agency, this study adopts the hedonic price model to test whether there is a green price premium in the Hangzhou housing market.

\section{Literature review}

During the past several decades, green building certifications have surged in many countries, such as LEED and Energy Star, BREEAM, Green Star, Green Mark and EPC (Energy Performance 
Certificate). At the same time, China has established an official rating system, the Chinese Green Building Label (CGBL), rating buildings from one to three stars, with three-star being the highest level [1].

These certifications have been widely used as green labels in the housing market to assess the green price premium. Fuerst and Mcallister [2, 3] found that LEED-certified and Energy Star-rated office buildings can command a sales price premium of $28 \%$ and $31 \%$, respectively. Zhang et al. [4] collected 176 green-labelled housing projects and 627 counterparts without green label around China to constitute the whole research sample. Compared with non-labelled housing, there was an average price premium of $6.4 \%$ for green-labelled housing. Besides, the price premiums for housing rated one-, two-, and three-star were $6.0 \%, 8.6 \%$, and $4.3 \%$, respectively, which indicated that green housing has been recognized by the housing market. Deng et al. [5] utilized the Singapore housing market data to determine the price premium for housing with Green Mark label. Through the adaptive choice-based conjoint analysis method, Heinzle [8] found that the price premium for green residential unit in Singapore ranged from 3.78\% (certified) to 7.98\% (platinum) and homebuyers were willing to pay for such premium. Zheng et al. [9] introduced a new green index to characterize the greenness of a housing unit depending on Google search. They documented that those units labelled as green attracted a price premium during the presale stage.

Most of previous studies used the hedonic price model to investigate the green price premium effect existed in the housing market. Lancaster [10] and Rosen [11] indicated that housing is a heterogeneous commodity and its characteristics may influence homebuyers' preferences and choices. To further research the green price premium, revealed preference method and stated preference method have been applied to seek reasons for the emergence of green price premium [6]. Based on the Hangzhou housing market, this study constructs the hedonic price model to evaluate the green price premium.

\section{Data and model}

The study area covers eight urban districts of Hangzhou, including Xihu District, Gongshu District, Shangcheng District, Xiacheng District, Jianggan District, Binjiang District, Yuhang District and Xiaoshan District. For a sample of 351 communities and 49097 newly-built housing units, the price of a housing unity is selected as the dependent variable and structure, neighborhood and location characteristics are chosen as independent variables.

To explore the premium effect of green marketing on housing prices, this study separates green marketing characteristics from neighborhood characteristics. Developer's reputation, eco-labelling and tech-labelling constitute green characteristic variables. Information of housing units are obtained from a well-known and reliable real estate website (http://www.soufun.com). Table 1 presents the specification, quantization and expected sign of the variables.

The hedonic price model is mainly expressed as linear functional form, logarithmic functional form and semi-logarithmic functional form. According to previous study results, this study adopts the logarithmic functional form, which is set up as follows:

$$
\ln P=\beta_{0}+\beta_{i} \times S_{i}+\beta_{j} \times N_{j}+\beta_{k} \times L_{k}+\beta_{m} \times G_{m}+\varepsilon .
$$

where $P$ is the transaction price of a housing unit; $S_{i}$ indicates the structure characteristic variables, including square, floor and decoration; $N_{j}$ indicates the neighborhood characteristic variables, including green rate and property management fee; $L_{k}$ indicates the location characteristic variables, including distance to West Lake, distance to Citizen Center and beltway; $G_{m}$ indicates the green marketing characteristic variables, including the developer's reputation, eco-labelling and tech-labelling; $\beta_{0}, \beta_{i}, \beta_{j}$, $\beta_{k}$, and $\beta_{m}$ are the coefficients to be estimated; and $\varepsilon$ is an error term. 
Table 1 Variable specification, quantization and expected sign

\begin{tabular}{|c|c|c|c|}
\hline $\begin{array}{l}\text { Characteristic } \\
\text { classification }\end{array}$ & Variables & $\begin{array}{c}\text { Variable definition and } \\
\text { quantization }\end{array}$ & Expected sign \\
\hline \multirow[t]{3}{*}{$\begin{array}{c}\text { Structure } \\
\text { characteristics }\end{array}$} & Square & $\begin{array}{l}\text { Area of housing construction } \\
\qquad\left(\mathrm{m}^{2}\right)\end{array}$ & + \\
\hline & Floor & Number of floor levels & $\begin{array}{c}\text { To be } \\
\text { determined }\end{array}$ \\
\hline & Decoration & $\begin{array}{l}1 \text { if the unit is decorated on } \\
\text { delivery; } 0 \text { otherwise }\end{array}$ & + \\
\hline \multirow[t]{2}{*}{$\begin{array}{l}\text { Neighborhood } \\
\text { characteristics }\end{array}$} & Green rate & $\begin{array}{l}\text { Ratio between green space area } \\
\text { and total land area (\%) }\end{array}$ & + \\
\hline & $\begin{array}{c}\text { Property management } \\
\text { fee }\end{array}$ & $\begin{array}{l}\text { Property management service } \\
\text { level of the community } \\
\left.\text { (yuan } /\left(\mathrm{m}^{2} \cdot \text { month }\right)\right)\end{array}$ & + \\
\hline \multirow[t]{3}{*}{$\begin{array}{c}\text { Location } \\
\text { characteristics }\end{array}$} & Distance to West Lake & $\begin{array}{l}\text { Straight-line distance from the } \\
\text { community center to West Lake } \\
\text { (km) }\end{array}$ & - \\
\hline & $\begin{array}{l}\text { Distance to Citizen } \\
\text { Center }\end{array}$ & $\begin{array}{l}\text { Straight-line distance from the } \\
\text { community center to Citizen } \\
\text { Center }(\mathrm{km})\end{array}$ & - \\
\hline & Beltway & $\begin{array}{l}1 \text { if the unit is located within the } \\
\text { beltway; } 0 \text { otherwise }\end{array}$ & + \\
\hline \multirow[t]{3}{*}{ Green marketing } & Developer's reputation & $\begin{array}{l}1 \text { if the unit is developed by a } \\
\text { green developer; } 0 \text { otherwise }\end{array}$ & + \\
\hline & Eco-labelling & $\begin{array}{c}1 \text { if the unit is eco-labelled; } 0 \\
\text { otherwise }\end{array}$ & + \\
\hline & Tech-labelling & $\begin{array}{l}1 \text { if the unit is tech-labelled; } 0 \\
\text { otherwise }\end{array}$ & + \\
\hline
\end{tabular}

\section{Results and discussion}

The OLS results of four models can be seen in Table 2. The adjusted R2 of every model is 0.885 , which indicates that all the models have good explanatory ability. All independent variables are statistically significant at the $10 \%$ significance level, and the signs of the regression coefficients are the same as expected.

To analyze the premium effect of green marketing on housing price, this study concerns on green marketing characteristic variables, namely developer's reputation, eco-labelling and tech-labelling. The coefficients of these three variables pass the $1 \%$ significance level test, which indicates that green marketing characteristics have been capitalized into Hangzhou housing prices. The price premium of housing unit which is developed by a green developer is $2.2 \%$. Furthermore, eco-labelling and tech-labelling have positive effects on housing prices, leading to the price premium of $2.9 \%$ and $3.7 \%$, respectively.

In contrast to the incremental costs shown in Table 4, the incremental costs of one-, two-, and three-star rated housing are less than 100 yuan $/ \mathrm{m}^{2}, 300$ yuan $/ \mathrm{m}^{2}$, and 500 yuan $/ \mathrm{m}^{2}$, respectively. And from Table 3, this study indicates that developer's reputation, eco-labelling and tech-labelling can generate price premium of $360 \mathrm{yuan} / \mathrm{m}^{2}, 474 \mathrm{yuan} / \mathrm{m}^{2}$, and $621 \mathrm{yuan} / \mathrm{m}^{2}$, respectively. This comparison implies that the price premium caused by green marketing can offset incremental costs, encouraging developers to make efforts for the construction of green housing. 
Table 2 Results of $\mathrm{M}_{\mathrm{t} 1}, \mathrm{M}_{\mathrm{t} 2}, \mathrm{M}_{\mathrm{t} 3}$, and $\mathrm{M}_{\mathrm{t} 4}$

\begin{tabular}{|c|c|c|c|c|c|c|c|c|c|}
\hline \multirow[t]{2}{*}{ Variables } & \multicolumn{2}{|c|}{$\mathrm{M}_{\mathrm{t} 1}$} & \multicolumn{2}{|c|}{$\mathrm{M}_{\mathrm{t} 2}$} & \multicolumn{2}{|c|}{$\mathrm{M}_{\mathrm{t} 3}$} & \multicolumn{3}{|c|}{$\mathrm{M}_{\mathrm{t} 4}$} \\
\hline & B & $\mathrm{t}$ & B & $\mathrm{t}$ & B & $\mathrm{t}$ & B & & VIF \\
\hline Constant & $10.434^{* * * *}$ & 435.803 & $10.440^{* * * *}$ & 435.689 & $10.471^{* * * *}$ & 440.312 & $10.407^{* * *}$ & 432.302 & \\
\hline Ln Square & $1.163^{* * *}$ & 276.099 & $1.161^{* * *}$ & 275.968 & $1.160^{* * * *}$ & 276.126 & $1.166^{* * *}$ & 276.907 & 1.046 \\
\hline Ln Floor & $0.011^{* * *}$ & 9.953 & $0.009^{* * * *}$ & 8.643 & $0.011^{* * *}$ & 9.824 & $0.011^{* * *}$ & 10.153 & 1.033 \\
\hline Decoration & $0.182^{* * *}$ & 72.149 & $0.188^{* * *}$ & 76.752 & $0.183^{* * *}$ & 72.949 & $0.173^{* * *}$ & 67.096 & 1.464 \\
\hline Green rate & $0.098^{* * *}$ & 3.648 & $0.126^{* * *}$ & 4.666 & $0.059^{* * * *}$ & 2.154 & $0.083^{* * *}$ & 3.038 & 1.084 \\
\hline $\begin{array}{c}\text { Property } \\
\text { management fee }\end{array}$ & $0.050^{* * *}$ & 32.203 & $0.052^{* * *}$ & 33.795 & $0.054^{* * *}$ & 34.806 & $0.053^{* * *}$ & 34.089 & 2.015 \\
\hline Ln West Lake & $-0.648^{* * *}$ & -193.997 & $-0.644^{* * *}$ & -193.369 & $-0.639^{* * *}$ & -190.242 & $-0.642^{* * *}$ & $\begin{array}{c}-190.38 \\
2\end{array}$ & 3.046 \\
\hline $\begin{array}{l}\text { Ln Citizen } \\
\text { Center }\end{array}$ & $-0.137^{* * *}$ & -46.560 & $-0.143^{* * *}$ & -49.697 & $-0.149^{* * *}$ & -51.227 & $-0.141^{* * *}$ & -47.425 & 3.290 \\
\hline Beltway & $0.125^{* * *}$ & 46.603 & $0.128^{* * *}$ & 46.738 & $0.118^{* * *}$ & 43.472 & $0.127^{* * *}$ & 45.865 & 2.366 \\
\hline $\begin{array}{l}\text { Developer's } \\
\text { reputation }\end{array}$ & $0.026^{* * *}$ & 12.702 & & & & & $0.022^{* * *}$ & 10.581 & 1.282 \\
\hline Eco-labelling & & & $0.025^{* * *}$ & 10.286 & & & $0.029^{* * * *}$ & 11.641 & 1.095 \\
\hline Tech-labelling & \multirow{2}{*}{\multicolumn{2}{|c|}{41938115}} & & & $0.041^{* * *}$ & 12.232 & $0.037^{* * *}$ & 10.719 & 1.213 \\
\hline F value & & & \multirow{2}{*}{\multicolumn{2}{|c|}{679}} & \multirow{2}{*}{\multicolumn{2}{|c|}{4192}} & \multirow{2}{*}{\multicolumn{3}{|c|}{$\begin{array}{c}34494.322 \\
0.885\end{array}$}} \\
\hline $\mathrm{R}^{2}$ (adj) & & & & & & & & & \\
\hline
\end{tabular}

Note: ${ }^{* * *},{ }^{* *}$, and ${ }^{*}$ represent significance at the $1 \%, 5 \%$, and $10 \%$ levels, respectively..

Table 3 Price semi-elasticity of green marketing characteristics

\begin{tabular}{cccccc}
\hline $\begin{array}{c}\text { Characteristic } \\
\text { classification }\end{array}$ & Variables & Coefficients & $\begin{array}{c}\text { Semi-elastic } \\
\text { coefficients }\end{array}$ & $\begin{array}{c}\text { Marginal price } \\
\text { (yuan) }\end{array}$ & $\begin{array}{c}\text { Average price } \\
\text { premium } \\
\text { (yuan } / \mathrm{m}^{2} \text { ) }\end{array}$ \\
\hline Green & $\begin{array}{c}\text { Developer's } \\
\text { reputation } \\
\text { Eco-labelling }\end{array}$ & 0.022 & 0.022 & 36759.49 & 359.69 \\
& 0.029 & 0.029 & 48455.69 & 474.14 \\
& Tech-labelling & 0.037 & 0.038 & 63493.67 & 621.28 \\
\hline
\end{tabular}

Table 4 Incremental costs for green housing (yuan/m2)

\begin{tabular}{cccc}
\hline Research & One-star rated & Two-star rated & Three-star rated \\
\hline Yip et al. [12] & 15.98 & 35.18 & 67.98 \\
Zhang et al. [7] & $<100$ & $<300$ & $<500$ \\
\hline
\end{tabular}

\section{Conclusion}

Based on new housing transaction data of Hangzhou in 2016, this study constructs the hedonic price model to analyze the effect of green marketing on housing prices. The main conclusion can be summarized that green marketing characteristics have price premium effects, and developer's reputation, eco-labelling and tech-labelling can command price premiums of $2.2 \%, 2.9$, and 3.7\%, respectively. The empirical results suggest that developers could establish proper green marketing strategy to advertise their housing products and attract more homebuyers to purchase such residential units.

However, some developers exaggerate the greenness of a housing unit, which means that they may use green words to describe their residential products and label their products as ecological or technological even though their products are not truly environmental friendly and energy efficient (Zheng et al., 2012). Therefore, developers should pay attention to credit operation in the real estate market and facilitate the development of real green housing. Besides, homebuyers need to distinguish the false self-advertisement and truly green-labelling. 


\section{References}

[1] L. Zhang, C. Sun, H.Y. Liu, S.Q. Zheng, The role of public information in increasing homebuyers' willingness-to-pay for green housing: Evidence from Beijing, Ecological Economics. 129 (2016) 40-49.

[2] F. Fuerst, P. Mcallister, New Evidence on the Green Building Rent and Price Premium, Real Estate \& Planning Working Papers. (2009)

[3] F. Fuerst, P. Mcallister, Green Noise or Green Value? Measuring the Effects of Environmental Certification on Office Values, Real Estate Economics. 39 (2011) 45-69.

[4] L. Zhang, H.Y. Liu, Quantitative analysis of the premium of green housing market in China, Journal of Engineering Management. 27(2013) 107-111.

[5] Y.H. Deng, Z.L. Li, J.M. Quigley, Economic returns to energy-efficient investments in the housing market: Evidence from Singapore, Regional Science and Urban Economics. 42 (2012) 506-515.

[6] L. Zhang, H. Zhao, X.K. Hu, Analysis of price premium for green housing in Beijing-the contrast of hedonic price method and willingness to pay, China Real Estate. 7 (2015) 21-27.

[7] L. Zhang, H.Y. Liu, J. Wu, The price premium for green-labelled housing: Evidence from China, Urban Studies. 54 (2016) 3524-3541.

[8] S.L. Heinzle, A.B.Y. Yip, M.L.Y. Xing, The Influence of Green Building Certification Schemes on Real Estate Investor Behaviour: Evidence from Singapore, Urban Studies. 50 (2013) 1970-1987.

[9] S.Q. Zheng, J. Wu, M.E. Kahn, Y.H. Deng, The nascent market for "green" real estate in Beijing, European Economic Review. 56 (2012) 974-984.

[10] K.J. Lancaster, A New Approach to Consumer Theory, Journal of Political Economy. 74 (1966) 132-157.

[11] S. Rosen, Hedonic Prices and Implicit Markets: Product Differentiation in Pure Competition, Journal of Political Economy. 82 (1974) 34-55.

[12] S. Yip, H.J. Li, L. Song, Study on the Economics of Green Buildings in China, China Architecture \& Building Press (2013). 